\title{
Taraxacum mongolicum extract exhibits a protective effect on hepatocytes and an antiviral effect against hepatitis $B$ virus in animal and human cells
}

\author{
YUAN-YUAN JIA $^{1 *}$, RONG-FA GUAN ${ }^{1 *}$, YI-HANG WU ${ }^{1}$, XIAO-PING YU ${ }^{1}$, WEN-YAN LIN ${ }^{2}$, \\ YONG-YONG ZHANG ${ }^{1}$, TAO LIU ${ }^{3}$, JUN ZHAO ${ }^{3}$, SHU-YUN SHI ${ }^{2}$ and YU ZHAO ${ }^{2}$
}

\author{
${ }^{1}$ Zhejiang Provincial Key Laboratory of Biometrology and Inspection \& Quarantine, Department of Pharmacy, \\ College of Life Sciences, China Jiliang University, Hangzhou, Zhejiang $310018 ;{ }^{2}$ College of Pharmaceutical Sciences, \\ Zhejiang University, Hangzhou, Zhejiang $310031 ;{ }^{3}$ College of Public Health, Xinjiang Medical University, \\ Ürümqi, Xinjiang 830011, P.R. China
}

Received May 22, 2013; Accepted January 22, 2014

DOI: $10.3892 / \mathrm{mmr} .2014 .1925$

\begin{abstract}
In order to validate the antiviral effect against hepatitis B virus (HBV) of Taraxacum mongolicum (T. mongolicum), the protective effect on hepatocytes, and antiviral properties against duck hepatitis B virus (DHBV) and HBV of T. mongolicum extract (TME) were evaluated in chemically-injured neonatal rat hepatocytes, DHBV-infected duck fetal hepatocytes and HBV-transfected HepG2.2.15 cells, respectively. The results demonstrated that TME at 50-100 $\mu \mathrm{g} / \mathrm{ml}$ improved D-galactosamine (D-GalN), thioacetamide (TAA) and tert-butyl hydroperoxide (t-BHP)-injured rat hepatocytes, and produced protection rates of $42.2,34.6$ and $43.8 \%$ at $100 \mu \mathrm{g} / \mathrm{ml}$, respectively. Furthermore, TME at 1-100 $\mu \mathrm{g} / \mathrm{ml}$ markedly inhibited DHBV DNA replication. Additionally, TME at $25-100 \mu \mathrm{g} / \mathrm{ml}$ reduced HBsAg and HBeAg levels and produced inhibition rates of 91.39 and $91.72 \%$ at $100 \mu \mathrm{g} / \mathrm{ml}$, respectively. TME markedly inhibited HBV DNA replication at $25-100 \mu \mathrm{g} / \mathrm{ml}$. The results demonstrate the potent antiviral effect of T. mongolicum against HBV effect. The protective of TME effect on hepatocytes may be achieved by its ability to ameliorate oxidative stress. The antiviral properties of TME may contribute to blocking protein synthesis steps and DNA replication. Furthermore, major components of TME were quantificationally analyzed. These data provide scientific evidence supporting the traditional use of TME in the treatment of hepatitis.
\end{abstract}

Correspondence to: Dr Yi-Hang Wu, Department of Pharmacy, College of Life Sciences, China Jiliang University, 258 Xueyuan Street, Xiasha Higher Education Zone, Hangzhou, Zhejiang 310018, P.R. China

E-mail: yihangwu@126.com

${ }^{*}$ Contributed equally

Key words: Taraxacum mongolicum, hepatocyte protective, duck hepatitis B virus, hepatitis B virus, neonatal rat primary hepatocytes, primary duck fetal hepatocytes

\section{Introduction}

Although safe and effective vaccination for the hepatitis B virus (HBV) is available for developing countries, according to the World Health Organisation, $>350$ million people are chronically infected with HBV (1). Long-term infection with HBV may lead to cirrhosis and hepatocellular carcinoma, and there continues to be no effective treatment for the millions of chronically infected individuals (2). Therefore, there is a pressing requirement for the development of safe and effective anti-HBV agents. The genus Taraxacum is a member of the family Asteraceae and widely distributed in the warmer temperate zones of the Northern Hemisphere. The perennial weed has been known for its curative properties since ancient times, and has been utilized for the treatment of various ailments, such as hepatitis, spleen and liver complaints, dyspepsia and anorexia (3). Taraxacum spp is used in a number of traditional and modern herbal medical systems to treat infections and bile and liver problems, and the use of Taraxacum spp in Asia, Europe and North America has been documented for the treatment of liver disorders (4).

Taraxacum mongolicum (T. mongolicum) Hand.- Mazz., also known as Chinese dandelion, is a member of the Taraxacum genus, which has been widely used in traditional Chinese medicine for its curative effects, particularly with liver disorders (5). Apart from being used pharmaceutically, the inflorescences, leaves and roots of T. mongolicum are processed into different food products. Additionally, T. mongolicum extracts (TME) are often used as flavor components in various food products, including alcoholic beverages, soft drinks, frozen dairy desserts, candy, baked goods, gelatins, puddings and cheese (6). Detailed phytochemical studies regarding T. mongolicum have been performed and have indicated that the phenolic and flavonoid compounds are the major components of the plant (6-10). Although T. mongolicum and herbal preparations containing it have been used by herbalists and other traditional healers to treat liver diseases for hundreds of years, modern pharmacological studies regarding T. mongolicum have rarely been reported. There have been limited numbers of reports regarding the biological activity 
of T. mongolicum, including its antitumor and antioxidative effects $(9,11)$. Furthermore, the effect of a traditional herbal preparation containing T. mongolicum was observed in patients with chronic hepatitis $B$. The results showed that liver enzymes were significantly more likely to return to normal levels in patients who had been administered the preparation. Of the 51 patients receiving the treatment, eight were effectively cured, while in the control group, only one person was cured (12). Though the curative properties of T. mongolicum have scientific support, this hypothesis is mainly based on the empirical findings over hundreds of years. Therefore, further research is essential.

In order to validate the antiviral effect of T. mongolicum against HBV, D-galactosamine (D-GalN), thioacetamide (TAA) and tert-butyl hydroperoxide (t-BHP)-induced neonatal rat primary hepatocyte damage models were used to assess the protective activity of TME on hepatocytes. The primary duck fetal hepatocytes infected with duck hepatitis B virus (DHBV) and HBV-transfected HepG2.2.15 cells were employed in order to evaluate the antiviral properties of TME against HBV. To quantify the active ingredients of TME, the total phenolic and flavonoid contents of TME were determined by colorimetry. In addition, the extract was analyzed by high-performance liquid chromatography (HPLC) and its principle components (caffeic acid and luteolin-7-O- $\beta$-D-glucopyranoside) were isolated and authenticated.

\section{Materials and methods}

Chemicals and reagents. Fetal bovine serum, 1640 medium and Dulbecco's modified Eagle's medium (DMEM) were purchased from Gibco-BRL (Grand Island, NY, USA). G418 was obtained from Invitrogen Life Technologies (Carlsbad, CA, USA). D-GalN, t-BHP, TAA, 3-(4,5-dimethylthiazol2-yl)-2,5-diphenyltetrazolium bromide (MTT), insulin, hydrocortisone and silybin were purchased from Sigma-Aldrich (St. Louis, MO, USA). Lamivudine was purchased from GlaxoSmithKline (China) Investment Co. Ltd. (Beijing, China). HBV DNA PCR-fluorescence quantitation kit and enzyme-immunoassay (EIA) kits for the detection of hepatitis B surface antigen (HBsAg) and hepatitis B envelope antigen ( $\mathrm{HBeAg}$ ) were provided by Shanghai Kehua Bio-engineering Co., Ltd (Shanghai, China). A plasmid mini preparation kit was purchased from Axygen Biosciences (Union City, CA, USA). The viral DNA kit was obtained from Omega Bio-Tek, Inc. (Norcross, GA, USA). SYBR ${ }^{\circledR}$ Premix Ex Taq $^{\text {TM }}$ II, Taq DNA polymerase, PMD-18T vector kit, DNA marker and conventional PCR reagents were obtained from Takara Biotechnology (Dalian) Co., Ltd. (Dalian, China). All other reagents were of the highest commercial grade available.

Preparation of TME. The whole herb of T. mongolicum Hand.-Mazz. was purchased from Haozhou herbal medicine market (Anhui, China) and verified by Professor Liurong Chen, College of Pharmaceutical Sciences, Zhejiang University (Hangzhou, China). The voucher specimen (TM-200405) of the plant was deposited at the herbarium of the College of Pharmaceutical Sciences, Zhejiang University. The dried whole herb of T.mongolicum $(10 \mathrm{~kg}$ ) was extracted three times with $95 \%$ ethanol. The extract was combined and concentrated under reduced pressure to generate a dark tar-like mass, which was dissolved in hot water. This solution was treated with $5 \%$ sodium carbonate, followed by three extractions with chloroform to remove lipophilic constituents. The remaining aqueous extract was further partitioned with ethyl acetate following acidification to $\mathrm{pH} 2$ using $1 \mathrm{~N}$ hydrochloric acid. The ethyl acetate fraction was washed with water to $\mathrm{pH} 7$ and condensed under reduced pressure $(0.06 \mathrm{Mpa})$ to afford a darkbrown powder (160 g), which was termed TME for further use.

Determination of total phenolics and flavonoids. The total phenolic content of TME was determined colorimetrically using ferric chloride-potassium ferricyanide reagent by a modified colorimetric method (13). Absorbance was measured at $763 \mathrm{~nm}$ with a UV-1600 Spectrophotometer (Beijing Rayleigh Analytical Instrument Co., Beijing, China). The total phenolic content of TME was calculated using the standard curve of caffeic acid. The total flavonoid content in TME was determined using sodium nitrite-aluminum nitrate-sodium hydroxide reagent by colorimetric assay (14). Absorbance was measured at $500 \mathrm{~nm}$ and the total flavonoid content of TME was calculated using the standard curve of rutin. Chemical analyses were repeated three times.

HPLC analysis of TME. TME was analyzed using a HPLC system (Waters 2695, Waters, Milford, MA, USA) and a symmetry ${ }^{\circledR} \mathrm{C} 18(5 \mu \mathrm{m}, 4.6 \mathrm{x} 150 \mathrm{~mm})$ column was used (Waters). The mobile phase consisted of two eluents: $0.1 \%$ acetic acid (B) and methanol (A). To achieve separation, the flow rate was set at $0.8 \mathrm{ml} / \mathrm{min}$ and $5 \mu \mathrm{l}$ sample was injected. The following gradient elution method was adopted: Initially, $90 \% \mathrm{~B}$ and $10 \% \mathrm{~A}$ maintained for $10 \mathrm{~min}$ followed by 55 min linear change to $0 \% \mathrm{~B}$ and $100 \% \mathrm{~A}$. The detection wavelength was set at $280 \mathrm{~nm}$ with a column temperature of $30^{\circ} \mathrm{C}$.

TME (100 g) was dissolved in $70 \%$ methanol. The solute was applied to a polyamide column and washed with water followed by $30,50,70$ and $100 \%$ of methanol. The separated fractions were repeatedly chromatographed on silica gel, reversed phase silica gel (RP-18) and Sephadex LH-20. The 30 and $50 \%$ methanol fractions afforded compound 1 (35 mg) and compound 2 (100 mg), respectively. Their structures were elucidated by spectroscopy (Varian INOVA $400 \mathrm{MHz}$ Nuclear Magnetic Resonance Spectrometer; Varian, Palo Alto, CA, USA) and compared with literature data $(15,16)$. The standard solutions of compound 1 and compound 2 were prepared in the same mobile phase for HPLC analysis.

Isolation and primary culture of neonatal rat hepatocytes. The experimental protocol was approved by the Animal Ethics Committee of Zhejiang Province (Zhejiang, China), in accordance with the international standard on the care and use of experimental animals. Rat hepatocytes were isolated from three-day-old Sprague-Dawley (Zhejiang Experimental Animal Center, Hangzhou, China) rats according to the method of Anil Kumar et al (17). The isolated hepatocytes were suspended in 1640 medium and subsequently transferred to 96 -well culture plates at a density of $\sim 1.0 \times 10^{5}$ cells $/ \mathrm{ml}$. Following hepatocyte attachment to the plate, cells were treated with hepatotoxic agents and analyzed in the following assays. 
Effect of TME on D-GalN-, TAA-or t-BHP-injured rat hepatocytes. Cytotoxicity induced by TME treatment was detected by MTT assay as follows: Hepatocytes were cultured in 1640 medium in the presence of $1-100 \mu \mathrm{g} / \mathrm{ml}$ TME for $48 \mathrm{~h}$ and subsequently $10 \mu \mathrm{l}$ MTT $(5 \mathrm{mg} / \mathrm{ml})$ was added to the cells in each well. Following culturing for $4 \mathrm{~h}$, the medium was removed and the blue formazan crystals that had formed were dissolved in dimethylsulfoxide. The absorbency of formazan generated from MTT was measured at $570 \mathrm{~nm}$ using an ELX 800 universal microplate reader (BioTek Instruments, Winooski, VT, USA). Cell survival was defined as the quantity of formazan produced relative to that of the untreated control cells.

The hepatocytes were incubated for a further $48 \mathrm{~h}$ in fresh culture medium containing 1-100 $\mu \mathrm{g} / \mathrm{ml}$ TME after the cells had been incubated for $8 \mathrm{~h}$ with $20 \mathrm{mM}$ D-GalN, $2 \mathrm{~h}$ with $8 \mathrm{mM}$ TAA and $1.5 \mathrm{~h}$ with $6.5 \mathrm{mM}$ t-BHP, respectively. Silibin was used as a reference drug. Hepatocyte injury was assessed according to cell viability. Cell viability was expressed according to protection rate (\%) and proliferation index.

Isolation and primary culture of duck fetal hepatocytes. Duck hepatocytes were isolated from 20-day-old embryonated, unhatched, duck eggs laid by DHBV-infected ducks according to a modified method (18). Cells were maintained at $1.0 \times 10^{5}$ cells $/ \mathrm{ml}$ in 1640 -medium containing $2 \mathrm{mM}$ glutamine, $1 \mu \mathrm{g} / \mathrm{ml}$ insulin, $7.5 \mu \mathrm{g} / \mathrm{ml}$ hydrocortisone, $10 \%$ (v/v) fetal bovine serum, $100 \mathrm{U} / \mathrm{ml}$ penicillin and $100 \mathrm{U} / \mathrm{ml}$ streptomycin at $37^{\circ} \mathrm{C}$ in a $5 \% \mathrm{CO}_{2}$ atmosphere. Congenital DHBV infection was confirmed by PCR assay on the viral DNA obtained from the allantoic fluid of duck embryos using DHBV-specific primers. The forward primer was 5'-AAC CAT TGA AGC AAT CAC TAG AC-3' and the reverse primer was 5'-ATC TAT GGT GGC TGC TCG AAC TA-3'.

Effect of TME on DHBV DNA replication in duck fetal hepatocytes. Cytotoxicity induced by TME treatment was measured using the MTT method as follows: Infected duck hepatocytes were cultured in 1640-medium with a concentration of $1.0 \times 10^{5}$ cells $/ \mathrm{ml}$ in the presence of $1-100 \mu \mathrm{g} / \mathrm{ml} \mathrm{TME}$ for six days and subsequently the MTT assay was performed as described previously. Cytotoxicity was described according to the quantity of formazan produced relative to that produced by the untreated control cells.

In order to measure the DHBV DNA levels, the infected duck hepatocytes were treated with varying concentrations of TME and the medium with the test compound was replaced every three days. On the third and sixth days, the DHBV DNA level in the replaced culture supernatants was detected with a SYBR-green dye-based quantitative PCR assay as follows: DHBV DNA was extracted and amplified with a Bio-Rad iQ5 Real Time PCR system (Bio-Rad Laboratories Inc., Irvine, CA, USA). The thermal program comprised of an initial denaturation at $94^{\circ} \mathrm{C}$ for $10 \mathrm{~min}$ followed by 40 amplification cycles at $94^{\circ} \mathrm{C}$ for $30 \mathrm{sec}, 55^{\circ} \mathrm{C}$ for $30 \mathrm{sec}$, and then $72^{\circ} \mathrm{C}$ for $45 \mathrm{sec}$. The forward primer was 5'-AGC TGG CCT AAT CGG ATT AC-3' and the reverse primer was 5'-TGT CCG TCA GAT ACA GCA AG-3'. SYBR $^{\circledR}$ Premix Ex Taq ${ }^{\mathrm{TM}}$ II was used to amplify and detect the DNA level during the reaction. A plasmid containing the DHBV genome was used to generate the standard curve for quantifying DHBV levels. Lamivudine was used as the reference drug.
Effect of TME on HBV expression and replication in HepG2.2.15 cells. HepG2.2.15 cells were provided by the State Key Laboratory for the Diagnosis and Treatment of Infectious Diseases, The First Affiliated Hospital, Zhejiang University (Hangzhou, China). The cells were maintained in DMEM containing $2 \mathrm{mM}$ glutamine, $10 \%$ (v/v) heat-inactivated fetal bovine serum and $380 \mu \mathrm{g} / \mathrm{ml}$ of $\mathrm{G} 418$ at $37^{\circ} \mathrm{C}$ (95\% humidity, $5 \% \mathrm{CO}_{2}$ ). The cytotoxicity of TME in HepG2.2.15 cells was analyzed by the MTT assay. The cells were seeded in a 96 -well plate at a concentration of $1.0 \times 10^{5}$ cells $/ \mathrm{ml}$. Varying concentrations of TME were applied to culture wells in triplicate. Following six days of incubation, the MTT assay was performed as described previously. Cytotoxicity was described according to the quantity of formazan produced, compared with that produced by the untreated cultures.

To determine HBV antigen and HBV DNA levels, HepG2.2.15 cells were treated with various concentrations of TME and the medium with test compound was replaced every three days. On the third day, the replaced medium was assayed for HBsAg and $\mathrm{HBeAg}$. On the sixth day, the replaced medium was measured for HBsAg, HBeAg and HBV DNA. Lamivudine served as a positive control. The HBsAg and HBeAg levels in the replaced culture supernatants were determined by using $\mathrm{HBsAg}$ and $\mathrm{HBeAg}$ EIA kits, respectively. The results were measured at $450 \mathrm{~nm}$ by a MULTISKAN MK3 multi-well microplate reader (Thermo Fisher Scientific Inc., Waltham, MA, USA).

HBV DNA levels in replaced culture supernatants were detected with a HBV DNA PCR-fluorescence quantitation kit. HBV DNA was extracted and amplified with Bio-Rad iQ5 Real Time PCR system (Bio-Rad, Hercules, CA, USA). The thermal program comprised of an initial denaturation at $94^{\circ} \mathrm{C}$ for $2 \mathrm{~min}$ followed by 40 amplification cycles each of two steps: $95^{\circ} \mathrm{C}$ for $5 \mathrm{sec}$ and $60^{\circ} \mathrm{C}$ for $30 \mathrm{sec}$. The forward primer was $5^{\prime}-\mathrm{CCG}$ TCT GTG CCT TCT CAT CTG-3', the reverse primer was 5'-AGT CCA AGA GTA CTC TTA TAG AAG ACC TT-3' and the Taqman probe was FAM-CCG TGT GCA CTT CGC TTC ACC TCT GC. A plasmid containing the full-length insert of the HBV genome was used to prepare the standard curve.

Statistical analysis. Experimental results were expressed as the mean \pm standard deviation and subjected to a one-way analysis of variance and Student's t-test. $\mathrm{P}<0.05$ was considered to indicate a statistically significant difference.

\section{Results}

Quantitation analysis of TME. The structures of compounds 1 and 2 were identified as caffeic acid and luteolin7-O- $\beta$ D-glucopyranoside, respectively (Fig. 1). The results of quantification indicated that the total phenolic acid content of TME was $36.27 \%$, using caffeic acid as the control standard, and the total flavonoid was $49.90 \%$ with rutin as the control. HPLC analysis demonstrated that caffeic acid and luteolin7-O- $\beta$-D-glucopyranoside were the major phenolic and flavonoid components in the extract and their absolute contents amounted to 0.6 and $1.0 \%$, respectively (Fig. 2).

Protective effect of TME on D-GalN-, TAA- or t-BHP-injured rat hepatocytes. The cytotoxicity of TME toward neonatal rat primary hepatocytes was tested. The result showed that TME, 
Table I. Effects of TME on D-GalN, TAA and t-BHP-injured primary neonatal rat hepatocytes.

\begin{tabular}{|c|c|c|c|c|c|c|c|}
\hline \multirow[b]{2}{*}{ Group } & \multirow[b]{2}{*}{$\begin{array}{l}\text { Concentration } \\
(\mu \mathrm{g} / \mathrm{ml})\end{array}$} & \multicolumn{2}{|c|}{ D-GalN-induced injury } & \multicolumn{2}{|c|}{ TAA-induced injury } & \multicolumn{2}{|c|}{ t-BHP-induced injury } \\
\hline & & $\begin{array}{l}\text { Protection } \\
\text { rate }(\%)\end{array}$ & $\begin{array}{l}\text { Proliferation } \\
\text { index }\end{array}$ & $\begin{array}{l}\text { Protection } \\
\text { rate }(\%)\end{array}$ & $\begin{array}{l}\text { Proliferation } \\
\text { index }\end{array}$ & $\begin{array}{l}\text { Protection } \\
\text { rate }(\%)\end{array}$ & $\begin{array}{l}\text { Proliferation } \\
\text { index }\end{array}$ \\
\hline Vehicle & - & - & - & - & - & - & - \\
\hline Chemical-control & - & - & - & - & - & - & - \\
\hline \multirow[t]{4}{*}{ Silybin } & 100 & 22.8 & 3.20 & 20.6 & 2.98 & 24.1 & 3.60 \\
\hline & 50 & 7.9 & 1.76 & 9.7 & 1.94 & 14.6 & 2.58 \\
\hline & 10 & 1.0 & 1.10 & 1.8 & 1.18 & 7.8 & 1.84 \\
\hline & 1 & 0.1 & 1.01 & - & 1.00 & 1.2 & 1.13 \\
\hline \multirow[t]{4}{*}{ TME } & 100 & 42.2 & 5.06 & 34.6 & 4.32 & 43.8 & 5.73 \\
\hline & 50 & 25.0 & 3.41 & 15.3 & 2.46 & 27.6 & 3.98 \\
\hline & 10 & 5.7 & 1.55 & 4.4 & 1.42 & 16.0 & 2.74 \\
\hline & 1 & 0.6 & 1.06 & 2.6 & 1.25 & 4.3 & 1.47 \\
\hline
\end{tabular}

The absorbance of three replicate wells was measured at $570 \mathrm{~nm}$. Cell viability was expressed with protection rate (\%) and proliferation index Protection rate $=$ (the mean absorbency value in experimental group - the mean absorbency value in chemical-control group) $/$ (the mean absorbency value in vehicle group - the mean absorbency value in chemical-control group) $\mathrm{x} 100 \%$. Proliferation index $=$ the mean absorbency value in experimental group / the mean absorbency value in chemical-control group. Dimethylsulfoxide $(0.1 \%)$ was used as the vehicle control. TME, Taraxacum mongolicum extract; D-GalN, D-galactosamine; TAA, thioacetamide; t-BHP, tert-butyl hydroperoxide.

A<smiles>O=C(O)/C=C/c1ccc(O)c(O)c1</smiles>

1.Caffeic acid<smiles>O=c1cc(-c2ccc(O)c(O)c2)oc2cc(OC(OC(O)CO)C(O)CO)cc(O)c12</smiles>

2. Luteolin-7-O- $\beta$-D-glucopyranoside

Figure 1. Structures of (A) caffeic acid and (B) luteolin-7-O- $\beta$-Dglucopyranoside from Taraxacum mongolicum extract.

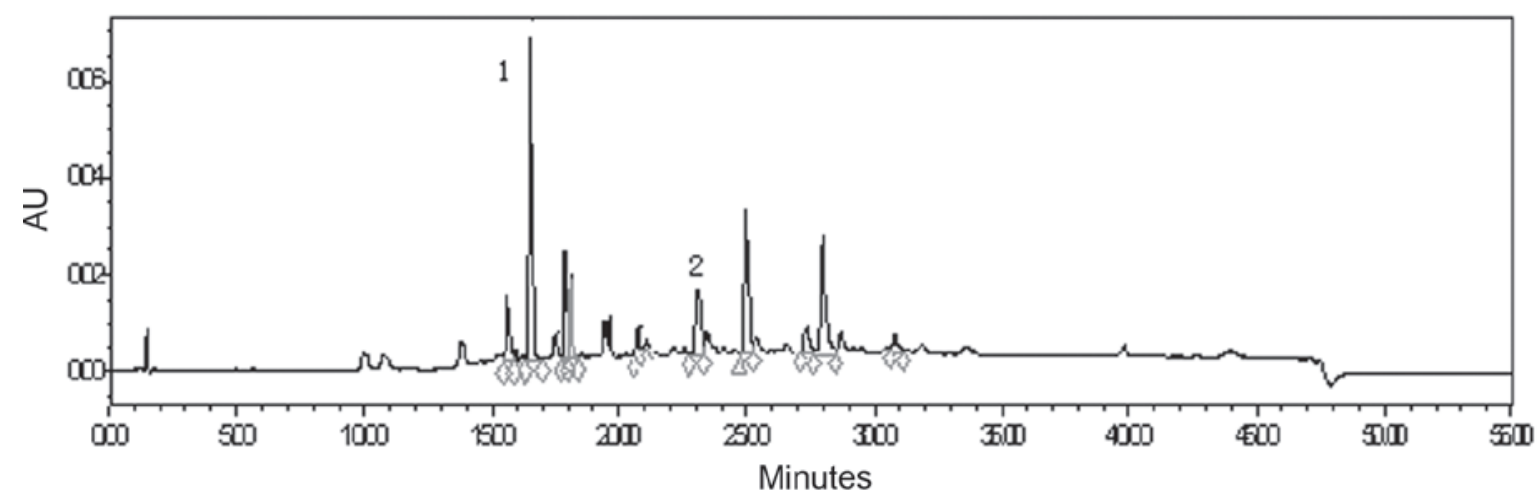

Figure 2. HPLC analysis of Taraxacum mongolicum extract. Numbers in figure indicate the main components of (1) caffeic acid and (2) luteolin-7-O- $\beta$-Dglucopyranoside.

at concentrations of $1-100 \mu \mathrm{g} / \mathrm{ml}$ was almost nontoxic to the cells. Cytotoxicity was induced in neonatal rat primary hepatocytes by exposure to $20 \mathrm{mM}$ D-GalN, $8 \mathrm{mM}$ TAA and $6.5 \mathrm{mM}$ t-BHP, respectively. Subsequently, the cells were treated with TME. As shown in Table I, TME concentrations between 1 and $100 \mu \mathrm{g} / \mathrm{ml}$ improved cell viability in a dose-dependent manner. Silibin, used as the reference drug, induced a similar, but weaker, effect, than that of TME at the same concentration.

Antiviral effect of TME against DHBV in primary duck fetal hepatocytes. The cytotoxicity test indicated that TME was nontoxic to primary duck fetal hepatocytes at concentrations 
Table II. Antiviral effect of TME against DHBV in infected primary duck fetal hepatocytes following cell treatment with test compound for 3 and 6 days.

\begin{tabular}{lccc}
\hline & & \multicolumn{2}{c}{$\log _{\text {DHBV-DNA }}(\operatorname{copy} / \mu 1)$} \\
\cline { 3 - 4 } Compound & Concentration $(\mu \mathrm{g} / \mathrm{ml})$ & 3 days & 6 days \\
\hline Vehicle & - & $3.714 \pm 0.036$ & $3.839 \pm 0.024$ \\
Lamivudine & 100 & $3.607 \pm 0.001^{\mathrm{b}}$ & $3.562 \pm 0.042^{\mathrm{c}}$ \\
TME & 100 & $3.393 \pm 0.088^{\mathrm{b}}$ & $3.346 \pm 0.036^{\mathrm{c}}$ \\
& 50 & $3.610 \pm 0.029^{\mathrm{a}}$ & $3.555 \pm 0.047^{\mathrm{c}}$ \\
& 25 & $3.630 \pm 0.050$ & $3.558 \pm 0.054^{\mathrm{b}}$ \\
& 10 & $3.697 \pm 0.024$ & $3.575 \pm 0.039^{\mathrm{c}}$ \\
& 1 & $3.707 \pm 0.024$ & $3.662 \pm 0.037^{\mathrm{b}}$ \\
\hline
\end{tabular}

$\log _{\text {DHBV-DNA }}$ values are expressed as the mean \pm standard deviation of three replicates. Dimethylsulfoxide $(0.1 \%)$ was used as the vehicle control. ${ }^{\mathrm{a}} \mathrm{P}<0.05,{ }^{\mathrm{b}} \mathrm{P}<0.01$ and ${ }^{\mathrm{c}} \mathrm{P}<0.001$ compared with the vehicle group. DHBV, duck hepatitis B virus; TME, Taraxacum mongolicum extract.

Table III. Antiviral effect of TME against HBV in HepG2.2.15 cells, after treating the cells with test compound for three days.

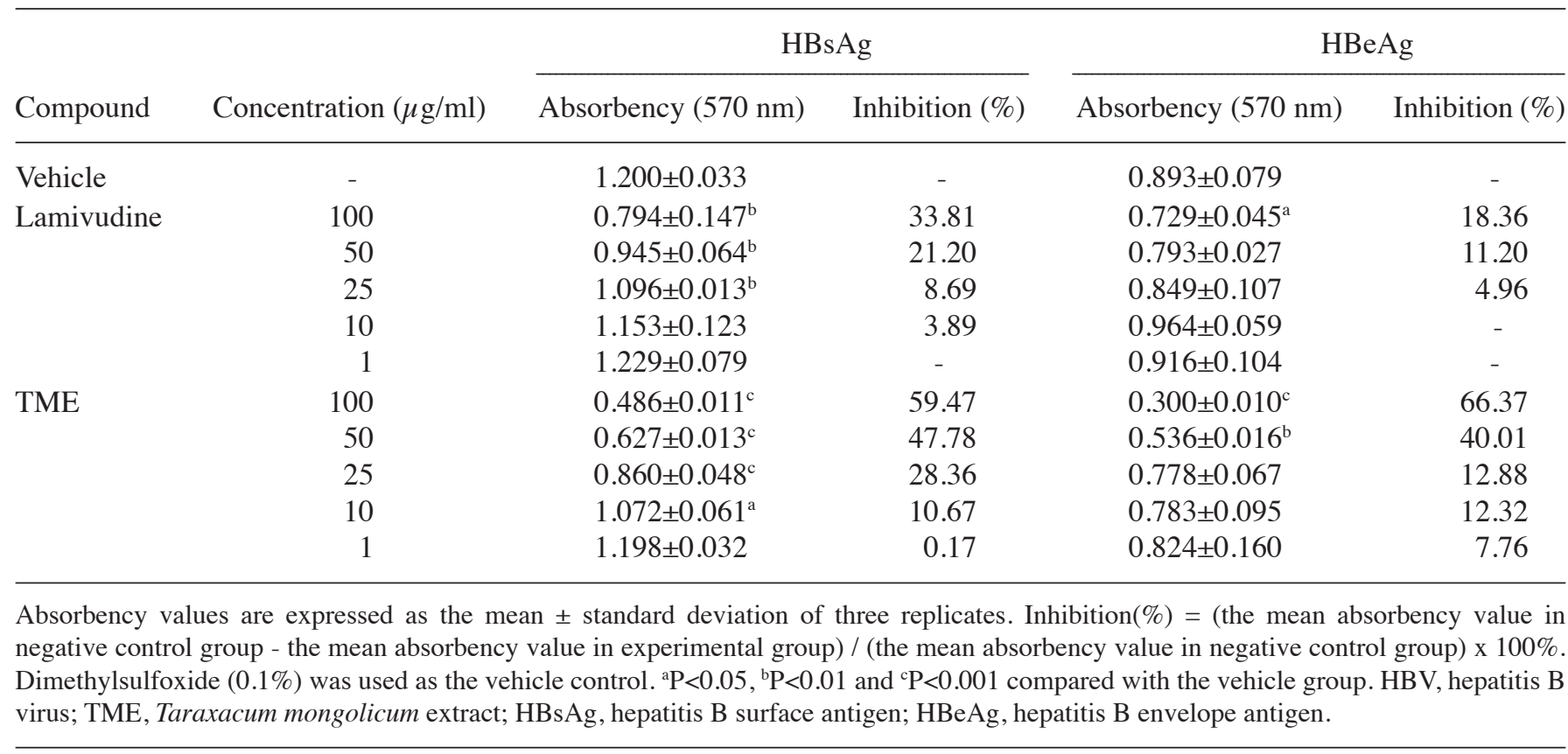

between 1-100 $\mu \mathrm{g} / \mathrm{ml}$. The effect of TME on the DHBV DNA level is shown in Table II. Following cell treatment with TME for three days, TME at concentrations between 50-100 $\mu \mathrm{g} / \mathrm{ml}$ significantly reduced DHBV DNA levels in culture supernatants compared with vehicle. On the sixth day, TME markedly inhibited the DHBV DNA replication at a concentration of $1-100 \mu \mathrm{g} / \mathrm{ml}$. Lamivudine, used as the standard drug, also induced a similar effect.

Antiviral effect of TME against HBV in HepG2.2.15 cells. Cellular toxicity tests revealed that TME was harmless to HepG2.2.15 cells at concentrations between 1-100 $\mu \mathrm{g} / \mathrm{ml}$. Expressions of $\mathrm{HBsAg}$ and $\mathrm{HBeAg}$ in culture supernatants were assayed after the cells had been incubated with TME for 3 days (Table III). The results indicated that TME had significant inhibitory effects on HBsAg expression at concentrations between $10-100 \mu \mathrm{g} / \mathrm{ml}$ and the HBeAg expression at concentrations between $50-100 \mu \mathrm{g} / \mathrm{ml}$. TME produced the maximum inhibition rates, on $\mathrm{HBsAg}$ and $\mathrm{HBeAg}$ expression at a concentration of $100 \mu \mathrm{g} / \mathrm{ml}$, of 59.47 and $66.37 \%$, respectively. The levels of HBsAg, HBeAg and HBV DNA in culture supernatants were measured after the cells had been treated with TME for 6 days (Table IV). At concentrations between 10-100 $\mu \mathrm{g} / \mathrm{ml}$, TME significantly inhibited HBsAg expression. At concentrations between 25-100 $\mu \mathrm{g} / \mathrm{ml}$, TME significantly reduced $\mathrm{HBeAg}$ levels. At a concentration of $100 \mu \mathrm{g} / \mathrm{ml}$, TME produced the maximum inhibition rates of 91.39 and $91.72 \%$ on $\mathrm{HBsAg}$ and HBeAg expression, respectively. Furthermore, TME markedly inhibited HBV DNA replication at 25-100 $\mu \mathrm{g} / \mathrm{ml}$.

\section{Discussion}

The beneficial role of hepatoprotectors in viral hepatitis is achieved through their inhibitory action on inflammatory and 
Table IV. Antiviral effect of TME against HBV in HepG2.2.15 cells, after the cells had been treated with the test compound for six days.

\begin{tabular}{|c|c|c|c|c|c|c|}
\hline \multirow[b]{2}{*}{ Compound } & \multirow[b]{2}{*}{ Concentration $(\mu \mathrm{g} / \mathrm{ml})$} & \multicolumn{2}{|c|}{ HBsAg } & \multicolumn{2}{|c|}{$\mathrm{HBeAg}$} & \multirow[b]{2}{*}{$\log _{\text {HBV-DNA }}(\operatorname{copy} / \mu 1)$} \\
\hline & & Absorbency & Inhibition (\%) & Absorbency & Inhibition (\%) & \\
\hline Vehicle & - & $2.497 \pm 0.009$ & - & $2.360 \pm 0.088$ & - & $5.137 \pm 0.032$ \\
\hline \multirow[t]{5}{*}{ Lamivudine } & 100 & $1.728 \pm 0.173^{b}$ & 30.60 & $1.921 \pm 0.145^{\mathrm{a}}$ & 18.24 & $4.923 \pm 0.127^{\mathrm{a}}$ \\
\hline & 50 & $1.905 \pm 0.095^{c}$ & 23.48 & $2.002 \pm 0.175^{\mathrm{a}}$ & 14.79 & $5.078 \pm 0.048$ \\
\hline & 25 & $2.150 \pm 0.091^{\mathrm{b}}$ & 13.67 & $2.084 \pm 0.126^{\mathrm{a}}$ & 11.32 & $5.081 \pm 0.036$ \\
\hline & 10 & $2.175 \pm 0.142^{\mathrm{a}}$ & 12.66 & $2.244 \pm 0.102$ & 4.52 & $5.228 \pm 0.024$ \\
\hline & 1 & $2.475 \pm 0.142$ & 0.61 & $2.387 \pm 0.169$ & - & $5.281 \pm 0.149$ \\
\hline \multirow[t]{5}{*}{ TME } & 100 & $0.214 \pm 0.010^{c}$ & 91.39 & $0.195 \pm 0.122^{\mathrm{c}}$ & 91.72 & $4.825 \pm 0.039^{c}$ \\
\hline & 50 & $0.696 \pm 0.031^{\mathrm{c}}$ & 72.06 & $0.472 \pm 0.004^{\mathrm{c}}$ & 79.93 & $4.954 \pm 0.077^{\mathrm{a}}$ \\
\hline & 25 & $1.631 \pm 0.119^{c}$ & 34.51 & $1.470 \pm 0.099^{c}$ & 37.43 & $4.978 \pm 0.075^{\mathrm{a}}$ \\
\hline & 10 & $1.445 \pm 0.098^{\mathrm{a}}$ & 41.95 & $2.118 \pm 0.138$ & 9.87 & $5.076 \pm 0.073$ \\
\hline & 1 & $2.557 \pm 0.031$ & - & $2.523 \pm 0.052$ & - & $5.208 \pm 0.067$ \\
\hline
\end{tabular}

Absorbency and $\log _{\text {HBV-DNA }}$ values are expressed as the mean \pm standard deviation of three replicates. Inhibition $(\%)=($ the mean absorbency value in negative control group - the mean absorbency value in experimental group) / (the mean absorbency value in negative control group) $x 100 \% .0 .1 \%$ dimethylsulfoxide was used as the vehicle control. ${ }^{a} \mathrm{P}<0.05$, ${ }^{\mathrm{b}} \mathrm{P}<0.01$ and ${ }^{\mathrm{c}} \mathrm{P}<0.001$ compared with the vehicle group. HBV, hepatitis B virus; TME, Taraxacum mongolicum extract; HBsAg, hepatitis B surface antigen; HBeAg, hepatitis B envelope antigen.

cytotoxic cascades induced by viral infection (19). Furthermore, these agents are capable of improving the regeneration process and normalizing liver enzymes through their effects on protein synthesis (19). The hepatocyte-protective effect of TME was evaluated by using hepatotoxic agents, such as D-GalN, TAA and t-BHP-induced neonatal rat hepatocyte injury models. Cell viability was expressed by the protection rate (\%) and proliferation index. The results indicated that TME possesses potent hepatocyte protective activity. Furthermore, TME afforded stronger protection on $D$-GalN-, TAA- or $t$-BHP-injured rat hepatocytes compared with the reference drug Silibin at the same concentration (Table I), thereby demonstrating the protective effect of TME on chemically injured hepatocytes. These data provided partial evidence for the clinical use of TME as a hepatoprotective drug.

D-GalN is a hepatotoxic agent that interferes with the metabolism of uridine diphosphate glucose and is often used in pharmacodynamics research to induce hepatic injury. It has been suggested that oxygen-derived free radicals released from activated hepatic macrophages are the primary cause of D-GalN-induced liver damage (20). Increased reactive oxygen species production has been reported in primary cultures of rat hepatocytes with damage induced by D-GalN (21). TAA is a thiono-sulfur-containing compound with liver-damaging and carcinogenic effects. Several studies using rats and cultured cells have indicated the involvement of oxidative stress in the etiology of TAA-induced liver damage $(22,23)$. t-BHP is often used in studies investigating the mechanism of cell injury initiated by acute oxidative stress. The compound is metabolized by cytochrome P-450 in hepatocytes or by hemoglobin in erythrocytes to free-radical intermediates, which in turn initiate lipid peroxidation and glutathione depletion. These changes compromise cellular integrity and cause cell injury in cultured hepatocytes $(24,25)$. In cells exposed to D-GalN, TAA and t-BHP, subsequent treatment with TME improved cell viability, suggesting that its ability to ameliorate oxidative stress may have contributed to the improvement of chemical-induced hepatocyte damage.

DHBV is similar to HBV in terms of the mechanism of replication and genome organization $(26,27)$. The natural route of transmission is from the bloodstream of persistently infected laying ducks to the egg, resulting in congenital infection (28). Congenitally infected ducks are at risk of developing hepatoma or secondary amyloidosis due to chronic stimulation of the immune system (29). The DHBV-infected primary duck hepatocyte model is a valuable model for hepadnavirus infection with high reproducibility and efficiency for evaluating novel agents directed against HBV (30). In the present study, TME at concentrations between $1-100 \mu \mathrm{g} / \mathrm{ml}$ significantly inhibited the replication of DHBV DNA in duck fetal hepatocytes, thus indicating that the antiviral effect of TME against DHBV is possibly associated with blocking viral DNA replication.

HepG2.2.15 cells are derived from human hepatoblastoma HepG2 cells that were transfected with a plasmid containing HBV DNA. The cells are capable of stably secreting viral particles in the culture medium (31). HBV is a small double-stranded DNA virus composed of an outer envelope containing HBsAg and an inner nucleocapsid consisting of $\mathrm{HBeAg}$ and hepatitis B core antigen. The viral core also contains a double stranded DNA genome and DNA polymerase. The presence of HBsAg is the most common marker for $\mathrm{HBV}$ infection, whereas $\mathrm{HBeAg}$ is used as an ancillary marker primarily to indicate active HBV replication and associated progressive liver disease (32). In the present study, TME at concentrations between $25-100 \mu \mathrm{g} / \mathrm{ml}$ significantly reduced $\mathrm{HBsAg}, \mathrm{HBeAg}$ and HBV DNA levels in HepG2.2.15 cells, thereby suggesting that the antiviral effect of TME against HBV is associated with blocking the steps of protein synthesis and DNA replication.

Phytochemical and HPLC assaying of TME led to the conclusion that this extract fraction contains a large quantity 
of phenolic and flavonoid compounds, such as caffeic acid and luteolin-7-O- $\beta$-D-glucopyranoside. Phenolic and flavonoid compounds exhibit several pharmacological activities, such as antioxidative, anti-inflammatory and antiviral effects $(33,34)$. TME exhibited a pronounced protective potential against oxidative damage in accordance with the description of the pharmacological effects of phenolic and flavonoid compounds in the aforementioned references. These data supported the former hypothesis that TME possesses efficacy against chemical-induced hepatocyte injury and virus infection. Therefore, phenolic and flavonoid compounds may be the major active components responsible for the biological activity of TME.

In conclusion, this investigation verifies the potent antiviral effect of TME against HBV in cell culture. Furthermore, the protective effect on hepatocytes and antiviral effects of TME were stronger than those of the reference drugs silibin and lamivudine, respectively. The protective effect of TME on hepatocytes was achieved by its ability to ameliorate oxidative stress. The antiviral effect of TME may contribute to blocking protein synthesis steps and DNA replication. This study provides scientific evidence for the use of T. mongolicum in treating hepatitis.

\section{Acknowledgements}

This study was supported by a grant from the Key Project of the Chinese Ministry of Education (grant no. 212073), the China Postdoctoral Science Foundation (grant no.20110491806) and the Project for Supporting Xinjiang through Science and Technology (grant no. 201191260).

\section{References}

1. Kao JH and Chen DS: Global control of hepatitis B virus infection. Lancet Infect Dis 2: 395-403, 2002.

2. Liaw YF: Therapy of chronic hepatitis B: current challenges and opportunities. J Viral Hepat 9: 393-399, 2002.

3. Schütz K, Carle R and Schieber A: Taraxacum - a review on its phytochemical and pharmacological profile. J Ethnopharmacol 107: 313-323, 2006.

4. Yarnell E and Abascal K: Dandelion (Taraxacum officinale and T. mongolicum). Integr Med 8: 35-38, 2009.

5. Song L, Hong X and Ding X (eds): Dictionary of Modern Chinese Medicine. People's Health Publishers, Beijing, pp2241, 2001 (In Chinese).

6. Shi S, Zhou H, Zhang Y, Zhao Y, Huang K and Liu S: A high-speed counter-current chromatography-HPLC-DAD method for preparative isolation and purification of two polymethoxylated flavones from Taraxacum mongolicum. J Chromatogr Sci 47: 349-353, 2009.

7. Ling Y, Bao Y, Guo X, Xu Y, Cai S and Zheng J: Isolation and identification of two flavonoids from Taraxacum mongolicum Hand.-Mazz. Zhongguo Zhong Yao Za Zhi. 24: 225-226, 1999 (In Chinese).

8. Shi S, Zhang Y, Zhao Y and Huang K: Preparative isolation and purification of three flavonoid glycosides from Taraxacum mongolicum by high-speed counter-current chromatography. J Sep Sci 31: 683-688, 2008.

9. Shi S, Zhao Y, Zhou H, Zhang Y, Jiang X and Huang K: Identification of antioxidants from Taraxacum mongolicum by high-performance liquid chromatography-diode array detection-radical-scavenging detection-electrospray ionization mass spectrometry and nuclear magnetic resonance experiments. J Chromatogr A 1209: 145-152, 2008.

10. Kim YH, Choo SJ, Ryoo IJ, Ahn JS and Yoo ID: Eudesmanolides from Taraxacum mongolicum and their inhibitory effects on the production of nitric oxide. Arch Pharm Res 34: 37-41, 2011.

11. Kim DH and Kim SH: Antitumor activity of Taraxacum mongolicum. J Korean Med Sci 16: 386-413, 1995.
12. Chen Z: Clinical study of 96 cases with chronic hepatitis B treated with jiedu yanggan gao by a double-blind method. Zhong Xi Yi Jie He Za Zhi 10: 71-74, 1990 (In Chinese).

13. Singh M, Singh SS and Sanwal GG: A new colorimetric method for the determination of pheonlics. Indian J Exp Biol 16: 712-714, 1978.

14. Dewanto V, Wu X, Adom KK and Liu RH: Thermal processing enhances the nutritional value of tomatoes by increasing total antioxidant activity. J Agric Food Chem 50: 3010-3014, 2002

15. Choudhary MI, Naheed N, Abbaskhan A, Musharraf SG, Siddiqui $\mathrm{H}$ and Atta-Ur-Rahman: Phenolic and other constituents of fresh water fern Salvinia molesta. Phytochemistry 69: 1018-1023, 2008.

16. Barberán FA, Hernández L, Ferreres F and Tomás F: Highly methylated 6-hydroxyflavones and other flavonoids from Thymus piperella. Planta Med 51: 452-454, 1985.

17. Anil Kumar PR, Bindu Menon, Anil Kumar TV and Kumari TV: Culture of neonatal rat liver cells: a preliminary observation. Trends Biomater Artif Organs 16: 34-47, 2002.

18. Borel C, Schorr O, Durand I, Zoulim F, Kay A, Trepo C and Hantz O: Initial amplification of duck hepatitis B virus covalently closed circular DNA after in vitro infection of embryonic duck hepatocytes is increased by cell cycle progression. Hepatology 34: 168-179, 2001.

19. Srivastava S, Srivastava AK, Srivastava S, Patnaik GK and Dhawan BN: Effect of picroliv and silymarin on liver regeneration in rats. Indian J Pharmacol 26: 19-22, 1994.

20. Hu HL and Chen RD: Changes in free radicals, trace elements, and neurophysiological function in rats with liver damage induced by D-galactosamine. Biol Trace Elem Res 34: 19-25, 1992.

21. Quintero A, Pedraza CA, Siendones E, et al: PGE1 protection against apoptosis induced by D-galactosamine is not related to the modulation of intracellular free radical production in primary culture of rat hepatocytes. Free Radic Res 36: 345-355, 2002.

22. Akbay A, Cinar K, Uzunalimoğlu O, Eranil S, Yurdaydin C, Bozkaya $\mathrm{H}$ and Bozdayi M: Serum cytotoxin and oxidant stress markers in nacetylcysteine treated thioacetamide hepatotoxicity of rats. Hum Exp Toxicol 18: 669-676, 1999.

23. Cascales M, Martín-Sanz P, Craciunescu DG, Mayo I, Aguilar A, Robles-Chillida EM and Cascales C: Alterations in hepatic peroxidation mechanisms in thioacetamide-induced tumors in rats. Effect of a rhodium (III) complex. Carcinogenesis 12: 233-240, 1991.

24. Thornalley P, Trotta RJ and Stern A: Free radical involvement in the oxidative phenomena induced by tert-butyl hydroperoxide in erythrocytes. Biochem Biophys Acta 759: 16-22, 1983.

25. Rush GF, Gorski JR, Ripple MG, Sowinski J, Bugelski P and Hewitt WR: Organic hydroperoxide-induced lipid peroxidation and cell death in isolated hepatocytes. Toxicol Appl Pharmacol 78: 473-483, 1985.

26. Mason WS, Seal G and Summers J: Virus of Pekin ducks with structural and biological relatedness to human hepatitis B virus. J Virol 36: 829-836, 1980.

27. Summers J and Mason WS: Replication of the genome of a hepatitis B-like virus by reverse transcription of an RNA intermediate. Cell 29: 403-415, 1982.

28. Omata M, Uchiumi K, Ito Y, Yokosuka O, Mori J, Terao K, Wei-Fa Y, O'Connell AP, London WT and Okuda K: Duck hepatitis B virus and liver disease. Gastroenterology 85: 260-267, 1983.

29. Duflot A, Mehrota R, Yu S, Barraud L, Trepo C and Cova L: Spectrum of liver disease and duck hepatitis B virus infection in a large series of Chinese ducks with hepatocellular carcinoma. Hepatology 21: 1483-1491, 1995.

30. Schultz U, Grgacic E and Nassal M: Duck hepatitis B virus: an invaluable model system for HBV infection. Adv Virus Res 63: $1-70,2004$.

31. Sureau C, Romet-Lemonne JL, Mullins JI and Essex M: Production of hepatitis B virus by a differentiated human hepatoma cell line after transfection with cloned circular HBV DNA. Cell 47: 37-47, 1986.

32. Huang RL, Chen CF, Feng HY, Lin LC and Chou CJ: Anti-hepatitis B virus of seven compounds isolated from Piper Kadsura (Choisy) Ohwi. Chin Med J 12: 179-190, 2001.

33. McDougall B, King PJ, Wu BW, Hostomsky Z, Reinecke MG and Robinson WE Jr: Dicaffeoylquinic and dicaffeoyltartaric acids are selective inhibitors of human immunodeficiency virus type 1 integrase. Antimicrob Agents Chemother 42: 140-146, 1998.

34. Sandhar HK, Kumar B, Prasher S and Sharma P: A review of phytochemistry and pharmacology of flavonoids. Int Pharm Sci 1: 25-41, 2011. 